\title{
The Perils of Global Citizenship ${ }^{1}$
}

\author{
BRETT BOWDEN
}

The notion of global citizenship has been with us since around $450 \mathrm{BC}$ when Socrates claimed that his country of origin was 'the world'. About 100 years later Diogenes the Cynic made a similar declaration as a 'citizen of the world'. These sentiments were echoed in the second century AD when Marcus Aurelius issued his famous declaration, 'my city and country so far as I am Antonius is Rome; but so far as I am a man, it is the world'. More recently, in response to an article by Richard Rorty extolling the virtues of 'national pride' and 'a sense of shared national unity', Martha Nussbaum has likewise declared herself to be a 'citizen of the world'. Despite this long history of claims to global or world citizenship, it is argued here that the notion is not only problematic but also undesirable.

\section{Introduction}

For almost 2500 years now people have intermittently proclaimed themselves to be some manner of global citizen or citizen of the world. The French essayist Montaigne recounts that 'When someone asked Socrates of what country he was, he did not reply, "of Athens", but "of the world". His was a fuller and wider imagination; he embraced the whole world as his city' (Montaigne, 1958, p. 63). Around 100 years after Socrates' declaration, when asked the same question, Diogenes the Cynic (404-323 BC) issued a similar response stating, 'I am a citizen of the world' (Diogenes, 1969, p. 146). More recently, Martha Nussbaum (1996a) has explicitly echoed Diogenes' declaration in response to an article by Richard Rorty in which he extols the virtues of 'national pride' and 'a sense of shared national unity' (Rorty, 1994). In turn, Nussbaum's proclamation has elicited a series of responses by a range of prominent political, social, legal, and literary theorists in which the countervailing merits of nationalism and cosmopolitanism are keenly debated (Cohen, 1996).

In this article I will set aside much of the debate over the respective virtues, or otherwise, of nationalism and cosmopolitanism (see Bowden, 2003), and focus on what I believe to be the under-theorised and problematic concept of global citizenship. I will argue that the concept, let alone the practice of global citizenship, is fraught with insurmountable problems; some of which stem from

Brett Bowden, Political Science Program, Research School of Social Sciences, Australian National University, Canberra, ACT 0200, Australia; tel.: + 61 (0)2 6125 2138; fax: + 61 (0)2 6125 3051; e-mail:brettb@coombs.anu.edu.au 
its close association with the ideals of cosmopolitanism, while in other ways it is incongruous with the general theory and ideal of citizenship. On one level, the ideal of global citizenship is inextricably linked to the West's long and torturous history of engaging in overzealous civilising-cum-universalising missions in the non-Western world. A relationship that is in part reflected in the fact that the vast majority of the recent claims to global citizenship originate from deep within Western academia. On another level, the notion of global citizenship is fraught with many of the same concerns and dangers associated with the condition of statelessness; an absence of the guarantee of rights and security that are generally taken for granted by citizens of stable sovereign states. But before discussing these problems in greater detail it is helpful to the understanding of the issues being raised here to first briefly elaborate on just what the ideal of citizenship entails.

\section{The Ideal of Citizenship}

Aristotle noted in The Politics that the nature of citizenship is contested and difficult to comprehensively define with any great satisfaction. And he was right. Nevertheless, it is important to have a general awareness of the broad origins and key developments that have contributed to contemporary understandings of the theory of citizenship. What follows, then, is a necessarily truncated overview of the key turning points and contributions that have helped to deliver the contemporary general theory of citizenship. ${ }^{2}$

As contemporary Western understandings of the ideal of citizenship draw heavily on components of the Ancient Greek and Roman articulations of the rights and obligations inherent in the role of the citizen, it is with them that we begin. The Athenian account of citizenship revolves around man's capacity to be both ruler and ruled: it is as the ruler of others in the oikos (the household) that qualifies him to join his fellow citizens as both the rulers and the ruled of the polis. As Aristotle tells it in The Politics:

$[F]$ or he who has a right to a share in the judicial and executive part of government in any city, him we call a citizen of that place; and a city, in one word, is a collective body of such persons sufficient in themselves to all the purposes of life. $(1912,1275 b$, p. 68)

To Aristotle and the Ancient Greeks the practice of citizenship, that is, the act of politics, or the actions of ruling and being ruled, 'is a good in itself, not the prerequisite of the public good but the public good or res publica correctly defined' (Pocock, 1992, p. 37). It is his capacity to rule that makes the citizen the highest order of being, at the same time, 'citizenship is not just a means to being free; it is the way of being free itself' (Pocock, 1992, pp. 35-7). That is to say that, for Aristotle, man is kata phusin zoon politikin, by nature he is born a political animal destined to live a political life, without which, as a cognitive and responsive being he is deprived of living a completely fulfilling and satisfying human life. Aristotle's musing on these matters continue to exert quite a strong influence, for they are formulations we remain attached to in a number 
of ways. Today, citizenship rights are no longer the exclusive preserve they once were in Ancient Greece, but it generally remains the case-in academic theorising if not so much in actual practice-that citizenship demands some meaningful say in the public and political arena. For today, just as it was then, policy decisions made in the public sphere on behalf of the citizens of any given polity inevitably impact on and influence the design of one's life plan.

The next significant development in terms of the changing conceptualisation of citizenship was the contribution of the Romans; under whose rule there is a shift from the citizen as a political being, as in Ancient Greece, to the citizen as a legal being. Attributed to the second century (c.130-180 AD) Roman jurist Gaius, ${ }^{3}$ in this formulation a "citizen" came to mean someone free to act by law, free to ask and expect the law's protection, a citizen of such and such a legal community, of such and such legal standing in that community' (Pocock, 1992, p. 40). In the hands of the Romans, citizenship thus becomes a legal status bringing with it rights to a range of things such as personal property and possessions, immunities and expectations. To be a Roman citizen meant to belong to a community governed by shared common laws that guaranteed a set of rights that were unique to one's fellow Roman citizens. Part of the price for securing these rights was that-unlike the role of their Greek predecessorsduring the Roman Empire the capacity of citizens to influence the design of the laws by which they would live eroded over time. Through this development the Romans give us an insight into the future condition of citizenship under systems of representative government, whereby citizens appoint representatives from their kind to legislate and govern on their behalf (see Hindess, 2000). The point to be made here is that under the Romans the ideal of citizenship came to include the right 'to make claims upon others and upon the civic process itself-claims that may all, at least in principle, be reducible to the language of rights' (Pocock, 1992, p. 50).

Taking a bit of a quantum leap forward to the modern era of the sovereign nation states system that evolved out of the 1648 Peace of Westphalia, we find that the states system paves the way for further shifts in the theorising of citizenship. One of the more influential of these is T.H. Marshall's analysis of the evolving principles of citizenship across eighteenth to twentieth century Britain. In short, Marshall identified three trends in the practice of modern citizenship: the first was developments in the field of civil rights pertaining to the legal status of citizens and the protection they were afforded before the law; the second related to the struggle for rights of political participation and the extension of suffrage; the third concerned social rights such as access to the means of guaranteeing a decent standard of living (Marshall, 1949/1992).

But this is now an account of citizenship that is coming under increasing attack from a range of perspectives. One of these critics is Bryan Turner who, in exploring the history of citizenship in Germany, France, Holland, England, and the United States, identifies two variables that impact on the nature of citizenship. The first concerns the 'passive' or 'active' nature of citizenship, that is, whether it is state driven or not, while the second relates to the level and quality of interaction between the public and private spheres. Out of this analysis, Turner contrasts a conservative view of citizenship (as passive and 
private) ... with a more revolutionary idea of active and public citizenship' (1990, p. 189). ${ }^{4}$ Having outlined a theory of citizenship, Turner then foreshadows the possible emergence of global citizenship as a consequence and 'political counterpart' to the globalisation of the world economy (1990, p. 213), the topic I will now make some preliminary remarks on.

If it is not evident from the above it will become increasingly evident below that the benefits and obligations of citizenship are inextricably linked to the citizen-state relationship. Hence, the first flaw in the idea of global citizenship derives from the nature of this relationship, for the "notion of a polis extended around the globe ... implies some form of world state, or federation of states', which in turn presupposes an extensive system of supra-national law (Featherstone, 2002, p. 3). As will be seen below, this was a position held by the Stoics, whose (questionable) benevolence and venerability many modern cosmopolitans place considerable stock in. It is also implied in Ulrich Beck's urging for the creation of 'cosmopolitan world politics' that is played out in a 'transnational framework'; through which he seeks the 'reinvention of politics, a founding and grounding of the new political subject: that is-cosmopolitan parties' (2002, p. 41). But as Derek Heater points out, the 'state ... is a reality, performs vital functions and therefore its preservation is in the interests of [hu]mankind. Conversely, world government has neither reality nor expedience' (1990, p. 229). In a similar line of thinking, the jurist L.C. Green argues that 'Any propaganda in favour of a world state remains just that'. Furthermore, the 'suggestion that a world citizenship could exist side by side with existing nationalities [as the Stoics sought] remains artificial and any "citizenship" so granted would be hollow in character, constantly giving way to the demands of existing sovereign states' (Green, 1987, p. 184). As Heater puts it rather emphatically, adapting Bentham's aphorism, 'World citizenship is nonsense; active world citizenship is nonsense on stilts' (1990, p. 229).

In essence, then, Hannah Arendt is right when she argues that 'Nobody can be a citizen of the world as he is the citizen of his country', and 'A citizen is by definition a citizen among citizens of a country among countries' (1973, p. 84). While not all advocates of global citizenship argue for it, there are enough who do to make it worth reissuing Arendt's warning that the 'establishment of one sovereign world state, far from being the prerequisite for world citizenship, would be the end of all citizenship. It would not be the climax of world politics, but quite literally its end' (1973, p. 84).

\section{Global Citizenship and Cosmopolitanism}

The notion of global citizenship is one that can be conceived of in a range of forms, for it has divergent advocates who address the topic from differing perspectives, although naturally there are many common points of concern and overlap. In its oldest manifestation it has long been associated with the ideals of cosmopolitanism; the links are evident in work as recent as Nussbaum's (1997) exposition of the twin concepts of world citizenry and cosmopolitan education and as old as Diogenes' declaration. Diogenes general ideas were passed on to 
the Cynics, a loose group of philosophers who in turn influenced Zeno of Citium (334-262 BC), the founder of the Stoic school of philosophy (see Pangle, 1998).

For its contemporary advocates, 'cosmopolitanism would seem to offer some kind of moral anchorage in a world' of increasing uncertainty, it might even sound "like a philosophically more interesting, historically grounded version of "multiculturalism", (Pagden, 2000, p. 3). But as we shall see, the ground on which this anchor rests is not nearly as morally sanguine as its modern adherents would have us believe. While acknowledging that there is a growing body of work that points to a plurality of cosmopolitanisms, including its extension to beyond its Western origins (see Levenson, 1971; Werbner, 1999; Pollock et al., 2000), as Lisa Hill accurately notes, 'Stoicism is the original source of Enlightenment cosmopolitanism and therefore contemporary internationalism' (2000, p. 66). Hence, the Stoic foundations of and influences on modern cosmopolitanism will be the focal point of discussion here.

Plutarch relays the Stoic's cosmopolitan leanings in On the Fortunes of Alexander as follows:

Indeed the Politeia of Zeno ... is directed to this one main point, that our life should not be based on cities or peoples each with its own view of right and wrong, but we should regard all men (pantas anthrōpous) as our fellow-countrymen and fellowcitizens, and that there should be one life and one order, like that of a single flock on a common pasture feeding together under a common law. (Baldry, 1965, p. 159)

This passage raises one of the key problematic issues for cosmopolitanism and global citizenship that will be addressed in more detail below. But before doing so, it is worth noting that what the Stoics were aiming for here was the realisation of the concept of oikoumenh or a world state. In effect, every person was thought of as born into and hence a citizen of two republicae: a particular city-state and the greater cosmopolis. In the event that such a situation should give rise to conflicting loyalties, a citizens' duties to the cosmopolis would always prevail (Hill, 2000, pp. 67-9). Stoicism effectively came to an end with the Roman Emperor Marcus Aurelius (AD 121-180), whose cosmopolitan bent is indicated by his famous declaration, 'my city and country, so far as I am Antonius is Rome; but so far as I am a man, it is the world' (Marcus Aurelius, 1949, p. 68).

Having declined with the Stoics, a brand of cosmopolitanism made something of a comeback in the guise of Neostoic humanism, a mode of thought perhaps best associated with the prominent sixteenth century Dutch humanist, Justus Lipsius (see Oestreich, 1982). But it was with Enlightenment thinkers such as Immanuel Kant and Thomas Paine that cosmopolitan political theory and the notion of world citizenship made its strongest return. ${ }^{5}$ For Paine, it can be seen where he writes, 'it may be said that I live in America ... [but] my principle is universal. My attachment is to all the world, and not to any particular part' (1777/1945, p. 146). It is confirmed in his insistence that 'Independence is my happiness, and I view things as they are, without regard to place or person; my country is the world, and my religion is to do good' (1791-2/1945, p. 414). But 
it is Kantian ethics-particularly his Categorical Imperative in the form of the human individual as constituting an end in itself, and not simply a means to an end-that remains the touchstone of modern cosmopolitan thought. Kant states:

Since the narrower or wider community of the peoples of the earth has developed so far that a violation of rights in one place is felt throughout the world, the idea of a law of world citizenship is no high-flown or exaggerated notion. It is a supplement to the unwritten code of the civil and international law, indispensable for the maintenance of the public human rights and hence also perpetual peace. $(1795 / 1963$, p. 105)

Kant's influence is evident in the three central tenets that Thomas Pogge identifies as common to most cosmopolitans. They are: (1) individualism-the primary unit of concern is the individual rather than families, ethnic, cultural or any other sub-groupings, nations, or states. These collectives indirectly derive their concern solely by virtue of the fact that they are made up of individuals who are, first and foremost, rights-bearing beings, and second, by chance happen to be members or citizens; (2) universality - the primacy of the individual as the central unit of concern is afforded to all human individuals without exception. It is not limited or restricted to people of certain classes, gender, colours, creeds, religions, or any other subset one wishes to distinguish; and (3) generality - the primary concern for the individual is extended to all humanity. One's concern for others does not stop at the border nor is it the privilege of only those who share one's own race, religion, or other features held in common (Pogge, 1992).

Drawing on these cosmopolitan foundations is a growing body of work advocating some form of global or world citizenship. For Jana Thompson the 'meaning of world citizenship' is, in part, determined by global distributive justice to the extent of 'the entitlement of each individual to an adequate share of the world's resources' (1998, p. 180). Muetzelfeldt and Smith (2002) examine the prospects of global citizenship through the lens of global civil society and global governance, while Roche (2002) broaches the subject using the Olympic Movement as a conduit. A slightly different liberal position to that occupied by Nussbaum is April Carter's account of 'liberal nationalism' in which 'there is a continuum between values and practices associated with local [liberaldemocratic] citizenship and the beliefs which underpin a conception of global citizenship' (1997, p. 76). Other accounts include those of Andrew Linklater (2002) and the work of the Commission on Global Governance, as expressed in Our Global Neighborhood (1995). However, the particular account of global citizenship I want to focus on here and highlight the flaws in is that which is most closely associated with the cosmopolitanism of Nussbaum and Pogge.

Not unlike the Stoics, Pogge argues that 'persons should be citizens of, and govern themselves through, a number of political units of various sizes, without any one political unit being dominant and thus occupying the traditional role of the state'. To this he adds that 'political allegiance and loyalty should be widely dispersed over these units: neighbourhood, town, county, province, state, region, and world at large' (1992, p. 58). Pogge's vision sounds very much like the 'concentric circles' analogy that Nussbaum borrows from the Stoic philosopher 
Hierocles; the first encircling the self, the next the family, and then so on outwards until 'the largest one, [encircles] humanity as a whole' (1996a, p. 9). This analogy returns us to the problem foreshadowed above, for the nature of the enterprise reveals itself when, citing Hierocles, Nussbaum argues that "Our task as citizens of the world will be to "draw the circles somehow toward the center", making all human beings more like our fellow city-dwellers' (1996a, p. 9). The central concern here is highlighted by Anthony Pagden, who, using Diogenes Laertius' recounting of Zeno's works, demonstrates that the Stoics fell well short of being all-embracing. To the contrary, Zeno's cosmopolis and the Stoic's affection were reserved for 'true citizens or friends', wherein 'friendship ... exists only between the wise and the good, by reason of their likeness to one another'. As Pagden states it, 'In calling upon all men to belong to a common deme or polis, Zeno was also, of course, making all men members of the deme or polis to which he belonged'. Moreover, 'far from extending a benign cultural relativity to all possible peoples, Stoicism was, in origin, a philosophy particularly well suited to the spread of empire' (Pagden, 2000, pp. 5-6). Or as Hill explains it, 'The cosmopolis is thus achieved via conquest' (2000, p. 72). Just as today, when Nussbaum and like-minded cosmopolitans declare themselves to be a 'citizen of the world', what they mean is that they are citizens of the cosmopolitan, globalised, liberal-democratic Western world that constitutes 'the center'. It is a world which outsiders are welcome to join (or are drawn into), only so long as they measure up or are happy to conform to Western values. Guiseppe Mazzini has captured the essence of this brand of cosmopolitanism quite succinctly:
All these soi disant cosmopolitans ... so soon as any question of action and therefore of organisation arises, invariably seek to make the centre of the movement their own country or their own city. They do not destroy nationality, they only confiscate all other nationalities for the benefit of their own. A chosen people, a Napoleon-people, is the last word of all their systems. (1890, Vol. III, p. 10)

Similarly, Enlightenment cosmopolitanism and the extension of 'global' citizenship to all is not the benign project its advocates would have us believe, for "cosmopolitanism is a distinctively European concept ... whose fortunes have been linked, for far longer than has generally been supposed, with the history of European universalism'. Its history runs a 'torturous course' through the 'construction of ... European overseas empires' and 'it is hard to see how cosmopolitanism can be entirely separated from some kind of "civilizing" mission, or ... the various imperial projects with which it has been so long associated' (Pagden, 2000, pp. 3-4). And one need not look too far back into history to find plenty of all too violent examples. Uday Singh Mehta provides us with ample evidence in his detailed account of Enlightenment universalism in Liberalism and Empire, in which he presents James and John Stuart Mill as archetypal advocates of the 'civilising' qualities of imperialism (Mehta, 1999). An associated concern with cosmopolitan thought is that it "preserves the idea of a single human destiny, a telos for all [hu]mankind and the conception of the future-and 
ineluctable-emergence of a single human culture' (Pagden, 2000, p. 19); a scenario which Isaiah Berlin quite rightly sees not as 'one [universal] culture, but the death of culture' (1991, p. 10).

There are further points of interest and or concern in Pogge's and Nussbaum's respective accounts of where one's allegiances should lie that are worth briefly recounting. In identifying a range of political units through which people should organise themselves, Pogge is attempting to move beyond the traditionally dominant role of the modern territorial state. But in effect, the alternative units identified by Pogge could almost all be classified as geographical or territorial units, just like the modern state. If one is endeavouring to outline a truly cosmopolitan schema that moves beyond the dominant role traditionally played by geopolitics, then why not include non-geographically based political units in that schema? ${ }^{6}$ In regards to Nussbaum's concentric circles analogy, this is also problematic in that it does not necessarily reflect the reality of how any given individual sees themselves and their place in the world. I suspect that rarely does the average person place themselves at the centre of the universe, rather, people are more likely to think of themselves as occupying a space somewhere on the fringe or at the margins of society. Instead of situating individuals at the centre of a series of concentric circles that extend to all humanity, perhaps a Venn diagram is a more useful way of representing any given persons place in the world and their range of overlapping relationships.

There are further shortcomings in Nussbaum's advocacy of cosmopolitanism that are worth noting but which can only be addressed here briefly. The first is her apparent willingness to dismiss the significance of the state and the state-making process; to which can be added her claim that states are defined by nothing more than a 'morally arbitrary boundary' (1996a, p. 14). On the contrary, as David Miller has endeavoured to establish, 'national boundaries may [indeed] be ethically significant' (1988, p. 647; 1993). Similarly, Nussbaum appears too ready to dismiss the significance of the passage of history; as seen in her assertion that it is purely 'an accident of birth' as to whether one is 'born a Sri Lankan, or a Jew, or a female, or an African-American, or a poor person' (1996b, p. 133). These are not all entirely accidental outcomes, the injustices of history may well have a good deal of say in whether one is born into poverty, or whether one is an African American because one's ancestors were stolen away by transatlantic slave traders.

\section{Global Citizenship and Statelessness}

Pierre Hassner's claim that 'It is precisely because they [refugees] are citizens of nowhere that they are potential citizens of the world' (1998, p. 274) is indicative of another dimension of the case for global citizenship. But similar to those outlined above, this postulation only serves to highlight the problems inherent in the concept of global citizenship more generally, rather than offer any new hope for the protection of the stateless. For as Michael Walzer notes, 'statelessness is a condition of infinite danger' (1981, p. 2; 1983, p. 32). This is because despite the United Nations Declaration of Human Rights claims to universality, it is still states that are invested with the primary responsibility for 
securing and maintaining those rights (Hindess, 2002, p. 130). This 'self-evident truth' is established no more clearly than in Thomas Jefferson's Declaration of Independence (Jefferson, 1776). So too, it is states that remain the primary culprits guilty of denying or abusing those same rights, even when it comes to liberal-democratic states that generally abide by the rule of law. For in practice, it is very much the case that stateless persons in the form of refugees or asylum-seekers do not enjoy the same rights and protections accorded to citizens of states such as Australia when they flee their homeland and arrive onshore 'illegally'.

Hannah Arendt has argued that the 'superfluity of the masses', or the condition of 'statelessness' is 'the newest mass phenomenon in contemporary history'. As she movingly states it:

No paradox of contemporary politics is filled with a more poignant irony than the discrepancy between the efforts of wellmeaning idealists who stubbornly insist on regarding as 'inalienable' those human rights, which are enjoyed only by citizens of the most prosperous and civilized countries, and the situation of the rightless themselves. (1967, p. 279)

Despite Hassner's suggestion to the contrary, as Arendt further notes, 'The Rights of Man, supposedly inalienable, proved to be unenforceable ... whenever people appeared who were no longer citizens of any sovereign state' (1967, p. 293). The greatest plight of the stateless is that they are denied the 'right to rights', or as Arendt puts it:

The calamity of the rightless is not that they are deprived of life, liberty, and the pursuit of happiness, or of equality before the law and freedom of opinion ... but that they no longer belong to any community whatsoever. Their plight is not that they are not equal before the law, but that no law exists for them. (1967, pp. 295-6)

And the international community that is so often spoken of as a protector of the weak is not a community of peoples into which stateless persons might be adopted. Rather, it is a community of states acting in the interest of states, and as such is part of an international system that has thus far proven to be incapable of fulfilling the role of protector.

In effect, cosmopolitans like Nussbaum are asking us to do away with the 'arbitrary' and 'morally irrelevant' identifying characteristics that make us who and what we are. Again sidelining the significance of the state-making process, Nussbaum asks:

Once someone has said, I am an Indian first, a citizen of the world second, once he or she has made that morally questionable move of self-definition by a morally irrelevant characteristic, then what, indeed, will stop that person from saying ... I am a Hindu first, and an Indian second, or I am an upper-caste landlord first, and a Hindu second? (1996a, p. 5) 
Here, Nussbaum is highlighting how one might get caught on the slippery slope that leads to some form of virulent exclusivist nationalism, but what is to stop someone from arriving at the final decision even if they reject the first move. The two are not necessarily connected. Rather, Nussbaum would have us pledge 'our fundamental allegiance to the world community of justice and reason' (1996a, p. 8). But whose conception of justice and reason is to be the standard bearer and who or what is one to identify with? How is one to conceptualise a global citizen and his or her global consciousness? As the sum total of all existing ethnic, national, and or cultural identities, surely not, for this is a virtually impossible state of mind to contemplate. (The answers to these questions are, of course, suggested by the very nature of Enlightenment cosmopolitanism outlined above. They are further reinforced in the work of modern cosmopolitans who hold up the economically globalised, liberal-democratic Western world as the ideal model to which all others aspire, or 'the center' toward which they are 'drawn'.) It is worth remembering at this point that a collective psyche or national identity is, ironically, unavoidably dependent upon the distinctiveness of the national identities beyond one's borders. In the absence of contrast and the relationship of the 'other' one's identity, or more accurately self-identification, is something of a non-issue. For something to compare and contrast the self or one's nation with is a basic necessity of self-awareness or self-recognition, and therefore, consciousness. It is also the case that without the contrasting of the other or others, let's say pluralism, a universalising cosmopolitanism may be 'empty' or soulless, as the likes of Isaiah Berlin believe it to be (1991, p. 9). Or as Pagden puts it, 'by embracing all values', cosmopolitanism 'lacks any' (2000, p. 4).

It is evident that not all cosmopolitans and 'global citizens' explicitly seek a total retreat of the sovereign states system in which international relations have been conducted since the Treaty of Westphalia was enacted. At the same time, it is equally clear that most cosmopolitans believe it is a system in need of serious reform. However, it is not entirely clear just what an alternative cosmopolitan vision might entail in practical (and political) terms. As the practicalities of enacting any cosmopolitan political project are revealed, its architects would do well to bear in mind the concerns aired by Arendt over the condition of statelessness or absence of belonging:

The great danger arising from the existence of people forced to live outside the common world is that they are thrown back, in the midst of civilization, on their givenness, on their mere differentiation ... The paradox involved in the loss of human rights is that such loss coincides with the instant when a person becomes a human being in general-without a profession, without a citizenship, without an opinion, without a deed by which to identify and specify himself-and different in general, representing nothing but his own absolutely unique individuality which, deprived of expression within and acting upon a common world, loses all significance. $(1967, \text { p. } 302)^{7}$ 


\section{Globally-minded Citizens}

Whilst I have argued that the notion of a global citizen or citizen of the world is not a viable one, this need not be at odds with the idea of what I would prefer to call globally-minded citizens (similar to what others have termed cosmopolitan citizenship, but which is not be confused with global citizenship), which I will now briefly outline. The possibility of being a globally-minded citizen is really only afforded to, or is only possible, if first one is a citizen of some particular state. In order to be a globally-minded or oriented citizen, first one needs to have a sense of belonging and an appreciation or understanding of their own history and culture. And by that I am not just referring to one's own personal identity. I mean what it is that goes into making up the nation in a broader sense, that is, the interaction of all quarters of the community; its indigenous, settler, and or immigrant components, or whatever the particular mix might be. From here we need not travel to every corner of the globe seeking every last detail about all the peoples of the world to be made aware of the true value of diversity. Having such self-awareness will hopefully enable us to be more open-minded and aware that beyond our respective borders are peoples who may be different to you and/or me, but who place a similar value on their identity. Furthermore, being a globally-minded citizen means being aware that actions taken in one part of the world can have an effect on people/nations beyond one's borders, and I am not just talking here about that much (over)used term globalisation. For instance, activities from atmospheric polluting and other environmentally detrimental actions, such as over-fishing, to unfair trade and/or unethical investment can have significant short and long-term transnational ramifications: acid rain and global warming do not recognise or adhere to (inter)national borders. In short, a globally-minded citizen of any given state would do well to follow that well-known catchphrase, 'think globally, act locally'. Such a perspective should help one and all to appreciate that people and cultures that are different to one's own are not something to be derided, ridiculed, or looked down upon as inferior or somehow backward and in need of overzealous (Western) tutelage.

\section{Conclusion}

I have argued that being a global citizen or citizen of the world is a less than viable proposition and is in many regards comparable to statelessness. Being a citizen of any given state is about having a legally constituted authority charged with looking out for and guaranteeing the welfare of you and your fellow citizens. Whether that be through providing armed forces to protect you from hostile invaders, providing services like basic education and health care, or providing the infrastructure-such as the police and an independent judiciaryessential for enforcing the law and order that is required in any fully functioning society. In essence, it is about having access to the institutions of government that you are entitled to make certain claims against in seeking basic and essential rights. As a stateless person you have no such institutions to call upon and thus no such rights. One need only ask any refugee in any refugee camp in the world 
if there is anything worse than being stateless or without a homeland-it is the epitome of homelessness. Anyone who has ever travelled abroad should be able to appreciate that without your government issued passport which effectively states that you are a good, decent and responsible citizen of this or that particular country, you are not going anywhere. As a refugee or stateless person you effectively fall between the cracks; there is no country obligated to be looking out for your interests and standing up for your rights. And to date, the various bodies that constitute the organisational instruments of the international system have proven largely ineffective in acting as second choice guarantor.

For cosmopolitan advocates of global citizenship there is an inescapable dilemma that is still to be addressed with any degree of satisfaction. If cosmopolites embrace and advocate only Western liberal-democratic values at the expense of non-Western values, then they are not truly multicultural pluralist cosmopolitans at all. Rather, they are (at best) cultural imperialists, perpetuating the Western Enlightenment's long history of universalism-cum-imperialism. On the other hand, if repelled by this prospect, cosmopolitans instead embrace cultural pluralism, that is, if they embrace all (or a broad range of) values, then it may very well be the case that they lack any, as Pagden suggests. And as Arendt rightly points out, as nothing more than human beings in general they lose all significance. This still to be resolved dilemma confronting cosmopolitans has been neatly summarised by Mazzini in his claim that 'the cosmopolitan has but two paths before him. He is compelled to choose between despotism and inertia' (1891, Vol. III, p. 8).

In medieval France municipal communities or villages were known by the term bourg, and one's legal right of membership in the bourg and entitlement to protection under its shared or common law became known as one's bourgeoisie. From these roots the terms citizen and bourgeois became virtually interchangeable as markers of one's membership in and entitlement to the privileges and protections accorded to members of the closed village community of shared law (Pocock, 1992, pp. 41-2). Today, I would argue that to be in a position to claim to be a global citizen is a privilege that is reserved for the modern, affluent global bourgeoisie, and even then it is a false claim. For as Michael Ignatieff notes, 'It is only too apparent that cosmopolitanism is the privilege of those who can take a secure nation state for granted' (1993, p. 9). When all is said and done, cosmopolitans are neither beyond nor above the state, for despite claims to the contrary, cosmopolitan, post-nationalist aspirations remain dependent upon the capacity of states to provide and guarantee a secure base for their citizens-without which such claims would not be possible.

\section{Notes}

1. An earlier version of this paper was presented at the 'Cultural Citizenship: Challenges of Globalisation' Conference, Deakin University, Melboure, Australia, December 2002. I am most grateful to Barry Hindess for his insightful comments and suggestions on an earlier draft of the paper. I would also like to thank Engin Isin, Leonard Seabrooke and three anonymous reviewers for their helpful comments. Much gratitude and appreciation is extended to Parminder Mann.

2. For a comprehensive account of the origins and history of the ideal(s) of citizenship from the Ancient Greeks to the modern era, see Heater (1990), especially Part One. 
3. Gaius is one of the 23 'lawgivers' whose marble bust adorns the walls of the United Sates' Congress House of Representatives Chamber.

4. For a more comprehensive overview of the inadequacies of Marshall's theory of citizenship, see the collection of essays in Turner (1993), particularly those by Barbalet, Hindess, Saunders, and Turner.

5. Walker argues that, in general, Paine's writing provides a more coherent and complete version of the cosmopolitan ideal, whereas 'Kant's cosmopolitan right was minimalist at best' (2000, pp. 67-9).

6. In relation to this reluctance, it has been suggested to me that one of the reasons behind it is that non-geographically based organisations pose so many difficult concerns and problems for governments of modern nation states. A good example of this is the difficulty states face in negating the threat posed to them and their citizens by loose-knit terrorist networks such as al-Qa'ida (Al-Qaeda).

7. Apart from the dire circumstances of the world's refugees and asylum-seekers, a good case in point is the plight of the not-quite-full-citizens or quasi-stateless peoples of the United States territory of Guam (see Stratham, 1998).

\section{References}

Arendt, H. (1967) The Origins of Totalitarianism (London, George Allen \& Unwin).

Arendt, H. (1973) 'Karl Jaspers: citizen of the world?', in: Men in Dark Times (Harmondsworth, Penguin). Aristotle (1912) The Politics (London, J.M. Dent \& Sons).

Baldry, H.C. (1965) The Unity of Mankind in Greek Thought (Cambridge, Cambridge University Press).

Beck, U. (2002) 'The cosmopolitan society and its enemies', Theory, Culture \& Society, 19(1-2), pp. 17-44.

Berlin, I. (1991) 'The ingathering storm of nationalism', New Perspectives Quarterly, 8(4), pp. 4-10.

Bowden, B. (2003) 'Nationalism and cosmopolitanism: irreconcilable differences or possible bedfellows?', National Identities, 5, forthcoming.

Carter, A. (1997) 'Nationalism and global citizenship', Australian Journal of Politics and History, 43(1), pp. 67-81.

Cohen, J. (Ed.) (1996) For Love of Country: Debating the Limits of Patriotism (Boston, Beacon Press).

Commission on Global Governance (1995) Our Global Neighborhood (New York, Oxford University Press).

Diogenes Laertius (1969) Lives of the Philosophers, A.R. Caponigri (Ed.) (Chicago, Henry Regnery Company, Gateway Edition).

Featherstone, M. (2002) 'Cosmopolis: an introduction', Theory, Culture \& Society, 19(1-2), pp. 1-16.

Green, L. (1987) 'Is world citizenship a legal practicality?', The Canadian Yearbook of International Law, XXV, pp. 151-85.

Hassner, P. (1998) 'Refugees: a special case for cosmopolitan citizenship?' in: D. Archibugi, D. Held and M. Köhler (Eds), Re-imagining Political Community: Studies in Cosmopolitan Democracy (Stanford, Stanford University Press).

Heater, D. (1990) Citizenship: The Civic Ideal in World History, Politics and Education (London and New York, Longman).

Hill, L. (2000) 'The two Republicae of the Roman Stoics: can a cosmopolite be a patriot?', Citizenship Studies, 4(1), pp. 65-79.

Hindess, B. (2000) 'Representation ingrafted upon democracy?', Democratization, 7(2), pp. 1-18.

Hindess, B. (2002) 'Neo-liberal citizenship', Citizenship Studies, 6(2), pp. 127-43.

Ignatieff, M. (1993) Blood \& Belonging (London, BBC Books and Chatto \& Windus).

Jefferson, T. (1776) The Declaration of Independence.

Kant, I. (1795/1963) 'Perpetual peace', in: L. Beck (Ed.), Kant on History (Indianapolis, Bobbs-Merrill).

Levenson, J.R. (1971) Revolution and Cosmopolitanism: The Western Stages and the Chinese Stages (Berkeley, University of California Press).

Linklater, A. (2002) 'Global citizenship', in: E.F. Isin and B.S. Turner (Eds), Handbook of Citizenship Studies (London, Sage).

Marcus Aurelius (1949) Meditations (London, J.M. Dent \& Sons).

Marshall, T.H. (1949/1992) 'Citizenship and social class', in: T.H. Marshall and T. Bottomore (Eds), Citizenship and Social Class (London, Pluto Press).

Mazzini, G. (1891) Life and Writings of Joseph Mazzini, VI Vols (London, Smith, Elder, \& Co.).

Mehta, U.S. (1999) Liberalism and Empire (Chicago and London, University of Chicago Press).

Miller, D. (1988) 'The ethical significance of nationality', Ethics, 98(4), pp. 647-62.

Miller, D. (1993) 'In defense of nationality', Journal of Applied Philosophy, 10(1), pp. 3-16. 


\section{Brett Bowden}

Montaigne (1958) 'On the education of children', in: Essays (Harmondsworth, Penguin).

Muetzelfeldt, M. and Smith, G. (2002) 'Civil society and global governance: the possibilities for global citizenship', Citizenship Studies, 6(1), pp. 55-75.

Nussbaum, M.C. (1996a) 'Patriotism and cosmopolitanism', in: J. Cohen (Ed.), For Love of Country: Debating the Limits of Patriotism (Boston, Beacon Press).

Nussbaum, M.C. (1996b) 'Reply', in: J. Cohen (Ed.), For Love of Country: Debating the Limits of Patriotism (Boston, Beacon Press).

Nussbaum, M.C. (1997) 'Kant and Stoic cosmopolitanism', Journal of Political Philosophy, 5(1), pp. 1-25. Oestreich, G. (1982) Neostoicism and the Early Modern State, B. Oestreich and H.G. Koenigsberger (Eds), D. McLintock (Trans.) (Cambridge, Cambridge University Press).

Pagden, A. (2000) 'Stoicism, cosmopolitanism, and the legacy of European imperialism', Constellations, 7(1), pp. 3-22.

Paine, T. (1777/1945) 'The American crisis VII', in: P. Foner (Ed.), The Complete Writings of Thomas Paine, Vol. II (New York, The Citadel Press).

Paine, T. (1791-2/1945) 'The rights of man', in: P. Foner (Ed.), The Complete Writings of Thomas Paine, Vol. II (New York, The Citadel Press).

Pangle, T.L. (1998) 'Socratic cosmopolitanism: Cicero's critique and transformation of the Stoic ideal', Canadian Journal of Political Science, 31(2), pp. 235-62.

Pocock, J.G.A. (1992) 'The ideal of citizenship since classical times', Queen's Quarterly, 99(1), pp. 33-55.

Pogge, T.W. (1992) 'Cosmopolitanism and sovereignty', Ethics, 103(1), pp. 48-75.

Pollock, S., Bhaba, H.K., Breckenridge, C.A. and Chakrabarty, D. (2000) 'Cosmopolitanisms', Public Culture, 12(3), pp. 577-89.

Roche, M. (2002) 'The Olympics and "global citizenship", Citizenship Studies, 6(1), pp. 165-81.

Rorty, R. (1994) New York Times, 13 February.

Statham, E.R. Jr. (1998) 'US citizenship policy in the Pacific territory of Guam', Citizenship Studies, 2(1), pp. 89-103.

Thompson, J. (1998) 'Community identity and world citizenship', in: D. Archibugi, D. Held and M. Köhler (Eds), Re-imagining Political Community: Studies in Cosmopolitan Democracy (Stanford, Stanford University Press).

Turner, B.S. (1990) 'Outline of a theory of citizenship', Sociology, 24(2), pp. 189-217.

Turner, B.S. (Ed.) (1993) Citizenship and Social Theory (London, Sage).

Walker, T.C. (2000) 'The forgotten prophet: Tom Paine's cosmopolitanism and international relations', International Studies Quarterly, 44(1), pp. 51-72.

Walzer, M. (1981) 'The distribution of membership', in: P. Brown and H. Shue (Eds), Boundaries: National Autonomy and its Limits (Totowa, NJ, Rowman and Littlefield).

Walzer, M. (1983/1989) Spheres of Justice: A Defense of Pluralism and Equality (Oxford, Basil Blackwell).

Werbner, P. (1999) 'Global pathways: working class cosmopolitans and the creation of transnational ethnic worlds', Social Anthropology, 7(1), pp. 17-35. 